Historic, Archive Document

Do not assume content reflects current scientific knowledge, policies, or practices. 



\title{
PLANT HAUPT BERRIES IN SUMMER AND FALL
}

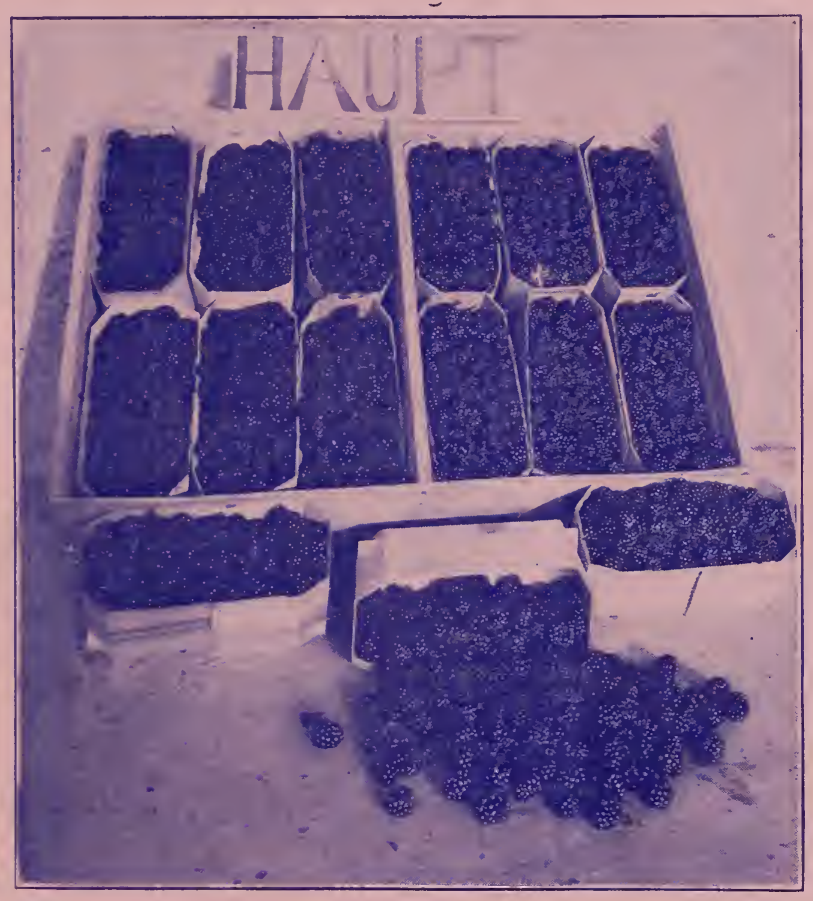

\section{THE AUSTIN NURSERY}

\author{
F. T. RAMSEY \& SON \\ AUSTIN, TEXAS
}

\section{THE VALUE OF NATIVES}

Plants that grow wild in any country will withstand diseases and the extremes of the weather better than plants that are not native. It is strange that nurserymen did not sooner begin paying attention to our native berries, but all men everywhere are inclined to undervalue native plants and flowers. Thus they cheat themselves. 


\section{THE HAUPT BERRY.}

The late Colonel Haupt, of Hays County (twenty miles from Austin), tramped the woods and prairies hunting dewberries. His friends helped him. He secured a new berry from Wharton County that is a cross between a blackberry and a dewberry, that eclipses anything we have ever seen.

Several years ago we paid Colonel Haupt $\$ 30.00$ for a hundred plants. After watching and testing them for a few years we decided it was the most valuable single variety of all fruits we had ever seen. We at once gave Mrs. Haupt $\$ 900.00$ for the privilege of digging the plants from her small patch for three years (practically all there were in existence), and later gave her $\$ 600.00$ to have the contract extended two years.

The Vine is a rank grower and bears so lavishly that the berries are fairly in heaps. Every bloom makes a berry, and every berry is sweet and large. It commences to ripen the last days of April and continues five weeks.

You never find a half pollenized berry on the Haupt.

The foliage is always deep green, even on lime land where fruit trees and most other berries are a yellow color. It is partial to rich black land. There are really two or more slightly different strains mixed. The cross pollenization is beneficial.

\section{ITS VALUE.}

The Haupt is the only berry we have ever planted extensively ourselves for market. Our two old rows paid at the rate of over $\$ 1000.00$ an acre, above cost of crates and picking. Every year, when other varieties almost failed entirely, the Haupt has yielded abundantly.

With a hundred vines of this berry a housekeeper may put up a year's supply of the finest jelly, jam, and canned berries, and do it in pleasant spring weather.

\section{CAN BE PLANTED IN SUMMER AND FALL.}

Like the dewberry of the southern strain it is an evergreen-that is, it grows all winter if the weather is not too severe.

Trees are planted in the winter because they are dormant-not growing. We observed that the severe dry spells we usually have in July and August caused these plants to suspend growth as completely as they do in winter, becoming possibly more dormant. This fact, together with our desire to get two crops of plants a year from the old patch and to get a large lot on our own place, prompted us to dig over the patch in August, 1908. We planted nearly 30,000 and practically every plant lived. Some died in a severe drouth a few weeks later. In 1909 we again dug and planted. We know the practice is a success.

It is cheaper than winter planting because the plants, with little or no care, get a good strong start in the fall and winter while the weeds and grass are not growing. The winter set plants require tedious care in competition with weeds and grass in the spring.

With careful handling we have planted in June with splendid results. The vines produced a crop the following spring. 


\section{A POLLENIZER FOR McDONALD.}

Of recent years the McDonald berry on many locations has failed to set good crops, often having but two or three drupes on a berry on account of not being perfectly pollenized. We find that every McDonald growing near the Haupt is loaded down with big, perfect, firm berries. In one instance, on the ends of some McDonald rows that came against a patch of Haupt, the berries were perfect, while on the other ends of the rows they were hardly worth picking. The planting of Haupt near McDonald brings the latter back to the productiveness of former years.

If you have McDonald, plant a row of Haupt on each side of them.

\section{NUMBER TO AN ACRE.}

If you plant Haupt in rows 6 feet apart and 4 feet in the row, you will need 1815 on an acre. It may pay to put them 7 by 5 feet, using 1244 on an acre.

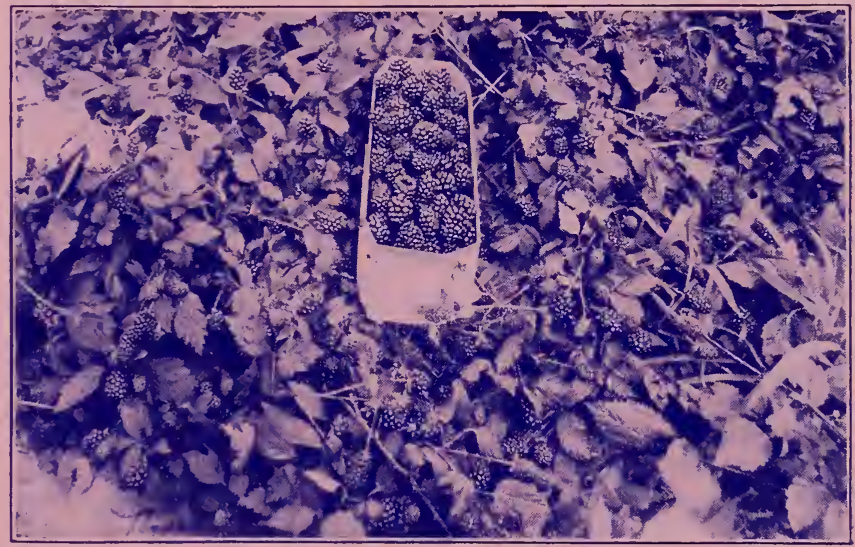

A Vine of Haupt Berry-the Same Every Year.

\section{HAVE GROUND IN GOOD CONDITION.}

Do not order unless your ground is in fine condition. Plow and harrow thoroughly. If it is moist from rain, the plants can be dropped in bottom of furrow, tramped down firm, and covered with a cultivator. When the young shoots begin to start, drag off the rows, thus killing a crop of young weeds.

If the ground is dry, each plant should be watered, and the loose soil mounded up to the top. However, in our own plantings, we always water every plant. As a matter of insurance, we believe it pays.

You can plant Haupt berries between cotton rows, but they are good enough to justify the plowing up of some cotton. 


\section{THE ADVANTAGES OF BERRIES.}

They begin to bear in one year and a failure is unknown.

They begin to ripen a month ahead of early peaches, and are the most profitable of all fruits, whether for home or market.

Marketmen say they can come nearer selling dewberries at every house than anything they ever put on their wagons.

A patch of Haupt pays in one year after you plant it, and at ten years of age pays just as well as at four years.

Mr. E. P. Norwood, who lives twelve miles from Austin, met us at our Farmers' Institute, and took us aside and made the following statement. We vouch for its truth. "You remember, I got a thousand dewberries from you a year ago last February. This spring when they began to bear, one of my renters proposed to pick and sell for half the money. I agreed to it, but I was to pick all I wanted, and I am sure that all I used were worth more than the plants cost. He turned me over $\$ 67.50$. So from one-third of an acre I have received average cotton rent for twenty-two years and a half in advance on a whole acre."

\section{THE FIRST OFFER OF THIS KIND EVER MADE.}

Hereafter we expect to be ready to fill orders for Haupt on short notice during July, August, September, and October, as well as during the winter months. If you have a good rain, or if you can water when you plant, let your order come right in, and we can have the plants to you within a very few days. No farm, market, or city garden should be without the Haupt berry.

\section{PRICES OF HAUPT.}

One dozen, by mail or express prepaid, $\$ 1.50$.

One hundred, by express prepaid, $\$ 6.00$.

One thousand, by express prepaid, $\$ 40.00$.

Our catalog rule of replacing at half price anything that dies in one year after planting applies also on summer shipped Haupt.

If you want at any time other sorts of berries or any kind of fruit trees, shades, pecans, or ornamentals, write for our new catalog. In it you will also find full directions for planting, pruning, watering, etc. If you wish to make any further inquiries, we are always glad to answer them.

We are offering to plant budded or grafted pecan trees in large lots and take pay for the trees that are alive at the end of the first season. If you are interested in Pecans, write for our Pecan Circular.

Catalog, special circulars, and any information we can furnish are sent free upon request.

\section{THE AUSTIN NURSERY}

\section{F. T. RAMSEY \& SON, Proprietors}

AUSTIN, TEXAS 


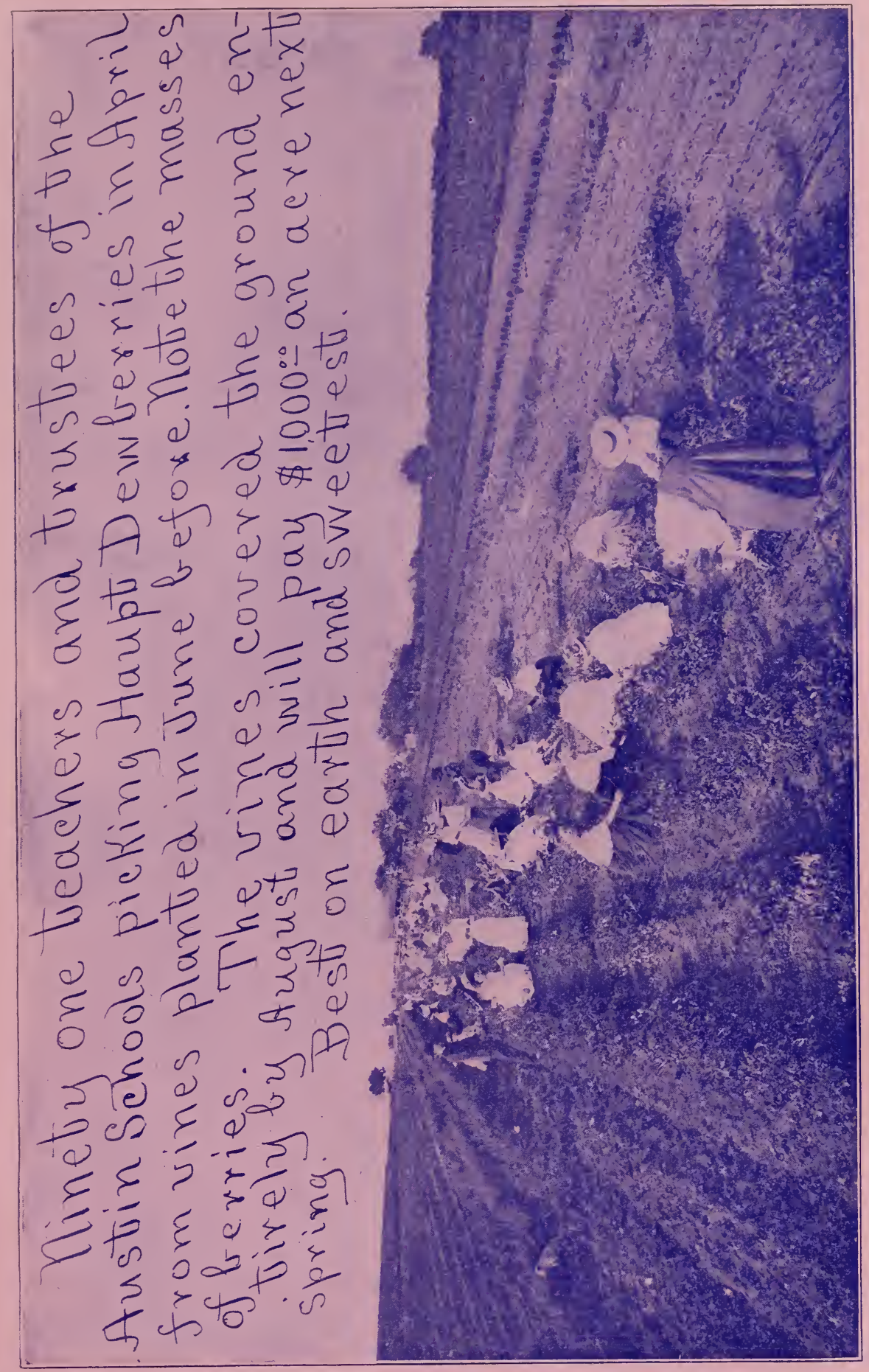




\section{POINTS FROM THE PRESS AND THE PEOPLE.}

\section{Everybody likes berries and berry fixings.}

It is cheaper to grow berries at home than it is to gather them wild, even if they do well around your place.

The roots of a dewberry go twice as deep in the ground as do the roots of a blackberry.

A dewberry patch never needs resetting. The roots, like pecan roots, never quit coming.

When you set a patch of Haupt, you have something that will be with you all your life.

A patch of Haupt gives you fine, sweet, fresh berries one-tenth of the year, and the best of anything ever put in jam jars or jelly glasses the balance of the year.

A pure dewberry bears one berry on each stem thrown up in the spring from the growth of the previous year. The Haupt bears in clusters of five to seven like a blackberry, but the vines spread on the ground and take root (tip) like a dewberry. A blackberry never does that.

Texas has more wild dewberries than all the balance of the world. She is the proud mother of some fine ones.

Never tie up or trellis a dewberry vine; the largest and sweetest berries grow near the ground.

A Bit of Science. The animal families that are of most use to man are the ones in which we find the most variation, in color, size and other qualities. The buffalo, zebra, and giraffe are of but little service to man. The tame pigeons of many colors lay more eggs than the one-colored wild ones. Chickens, with their countless colors, lay more eggs than any other fowls. Dogs know more than do wolves.

There has never been on this earth a country occupied by a people that differed so widely and in so many different degrees of temperament, complexion, form, and physiognomy as do the Americans of this day, and none ever went forward so rapidly in the fields of mental and physical effort, the sum of which we call success.

You never saw two pecan trees nor two dewberry vines alike, unless they were propagated from one seedling. A nut or a seed of these never produces its exact like. Other nuts are monoform, or nearly so.

When we consider that the pecan and the dewberry are the only ones in their respective families that possess the quality of variablenessa quality we find only in the best of fruits and animals-no one can hesitate in declaring them the princes of their kind. This quality of persistent or universal variation seems developed to a higher degree in them than in anything else in the animal or vegetable kingdoms. Is this a newly written law? A knowledge of it is helpful. F. T. R. 


\section{ORDER BLANK.}

F. T. RAMSEY \& SON, Austin, Texas:

Please send to me by mail or express prepaid the following plants:

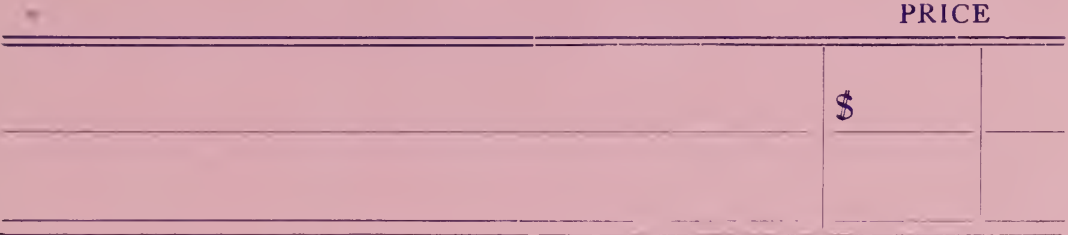

Amount enclosed, cash, check or money order, $\$$

If plants are to be paid for on arrival, mark C. O. D. here

\section{REMARKS:}

If possible, I should like to have the above order arrive about (date).

In making this order, it is understood that you will replace at half price, if I desire it, all plants that die the first year after planting.

My name.

Postoffice.

Express office.

Date.

Salesman.

Note-We can always ship promptly, and upon receipt of your order will notify you before shipment is made, so that there will be little or no delay before or after plants are sent. We guarantee them to arrive in first-class condition.

(SEE OVER)

F. T. RAMSEY \& SON. 
We shall appreciate it if you will witite below the names of a few friends who might be interested in our catalog and special circulars.

\section{MAMES OF THOSE WHO NEED A CATALOG}

ADDRESS 